\title{
Lymph Node Metastasis after a Soft Tissue Sarcoma of the Leg: A Case Report and a Review of the Literature
}

\author{
S. D. Nelen, ${ }^{1}$ F. J. Vogelaar, ${ }^{1}$ F. Gilissen, ${ }^{1}$ J. C. Van der Linden, ${ }^{2}$ and K. Bosscha ${ }^{1}$ \\ ${ }^{1}$ Department of Surgery, Jeroen Bosch Hospital, Henri Dunantstraat 1, 5223 GZ 's-Hertogenbosch, The Netherlands \\ ${ }^{2}$ Department of Pathology, Jeroen Bosch Hospital, Henri Dunantstraat 1, 5233 GZ 's-Hertogenbosch, The Netherlands
}

Correspondence should be addressed to S. D. Nelen; sdnelen@gmail.com

Received 15 November 2012; Accepted 23 December 2012

Academic Editors: C. Barnett, C. De Crea, and M. Nikfarjam

Copyright (c) 2013 S. D. Nelen et al. This is an open access article distributed under the Creative Commons Attribution License, which permits unrestricted use, distribution, and reproduction in any medium, provided the original work is properly cited.

\begin{abstract}
Introduction. Soft tissue sarcomas (STSs) represent 1 percent of all adult malignancies and sarcomas only rarely spread to the regional lymph nodes. Case Presentation. We present a case of a woman with a dermatofibrosarcoma protuberans and a sarcoma not therwise specified of the lower extremity. The patient had no distant metastasis during follow-up, but did develop a regional lymph nodemetastasis (RLNM) in the groin. We reviewed the literature about RLNM in STSs. Discussion. Reviewing the literature we see that within specific histological types RLNM occurs as often as distant metastasis. Furthermore RLNM occurs in over $10 \%$ for specific histological types and in $24 \%$ of all patients with a soft tissue sarcoma of the lower extremity. Except for radical lymphadenectomy with a 5 -year survival rate of $46 \%$ there is no appropriate treatment. Conclusion. The risk for a RLNM in certain histological types and anatomical locations might transcend the risk for a distant lung metastasis.
\end{abstract}

\section{Introduction}

Soft tissue sarcomas (STSs) represent 1 percent of all adult malignancies and up to 6 percent of all childhood cancers [1-4]. In 2010, there were 10.520 cases of soft tissue sarcomas in the United States and 3920 patients died from this disease [5]. For dermatofibrosarcoma protuberans (DFSP) the annual incidence in the United States between 1973 and 2002 was 4.2 per 1.000.000 [6]. In the Netherlands the annual incidence of STS was 34 per 1.000 .000 for men and 28 per 1.000 .000 for women in 1997 [3].

The pattern of metastatic spread is usually haematogenous; lymphatic spread is very rare $[7,8]$. We present a case of a patient with a inguinal lymph node metastasis 4 years after resection of a STS. A review of the literature will be described.

\section{Case Presentation}

A 68-year-old Caucasian woman with hypertension and diabetes type 2 was treated in 2001 because of a mass of unknown histological origin of the right upper leg. She underwent a local resection of the tumor and pathological examination showed a DFSP. It was found to be a DFSP in histological research due to proliferation of atypical fusiform mesenchymal cells, with multinuclear giant cells which were sometimes arranged in rosettes (Figure 1). Moreover, the immunoprofile showed mainly positivity with vimentin $(++)$, desmin (+), and CD-68 (+) which would mostly fit the diagnosis of a DFSP, a malignant fibrous histiocytoma was in the differential diagnosis. Due to tight surgical margins, a re-resection found place with margins of more than 2 centimetres.

During followup a new mass was discovered at the site of the scar 6 years later. Local surgical excision was performed and pathological examination showed a high grade sarcoma not otherwise specified (NOS), grade III. Histological research showed proliferation of a more cellular tumor process with more and bizarre mitotic figures (Figure 2). The tumor cells showed, compared to the primary tumor in 2001, less differentiation. The diagnosis of a NOS sarcoma was also based on the immunoprofile which was only positive for vimentin and the previously positive markers were considered negative (CD-68, desmin). After surgical excision the tumor was treated with radiotherapy. Ultrasound of the right groin showed no regional lymph node metastasis 


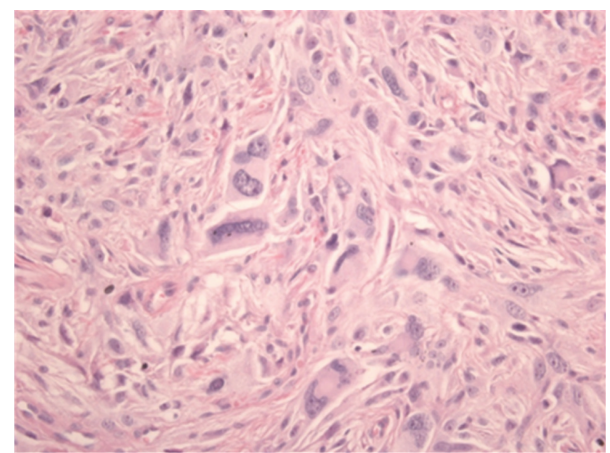

FIgURE 1: Microscopic view (400x) of the tumor of the right upper leg. The histopathological pattern, immunoprofile, and localization of this subcutaneous tumor favor the diagnosis of DFSP.

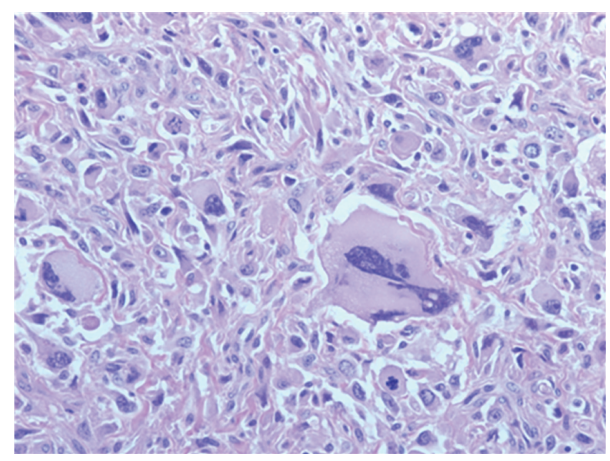

FIgURE 2: Microscopic view (400x) of the second tumor of the right upper leg. Based on the morphology, clinical history, and immunoprofile it was diagnosed to be a localization of a high grade sarcoma NOS.

(RLNM) and there were no abnormalities seen at the chest $\mathrm{X}$-ray.

During further follow-up a groin mass was found 4 years later. CT examination revealed a large lymph node (Figure 3) without any other evidence of distant disease. An ultrasound-guided biopsy was performed and showed a metastases of the sarcoma. A superficial regional lymph node dissection was performed which showed one positive lymph node out of nine dissected and Cloquet's node negative. Pathological-anatomical study showed a metastasis of a high grade sarcoma NOS (Figure 4). Until now, further followup with chest X-ray and CT scan showed no abnormalities.

\section{Discussion}

3.1. Metastatic Pattern. In STS, distant metastases are relatively common, occurring in approximately $10 \%$ of patients. In patients with a sarcoma of the extremity, metastases will develop in up to $25 \%$ of patients $[13,14]$. In contrary only $1 \%$ of patients with DFSP have distant metastases $[6,15]$. Distant metastases occur especially in patients having had large, high grade tumors that are deep located to or nearby the fascia. Up to 83 percent of the distant metastases in STS occur in the lung $[16,17]$.

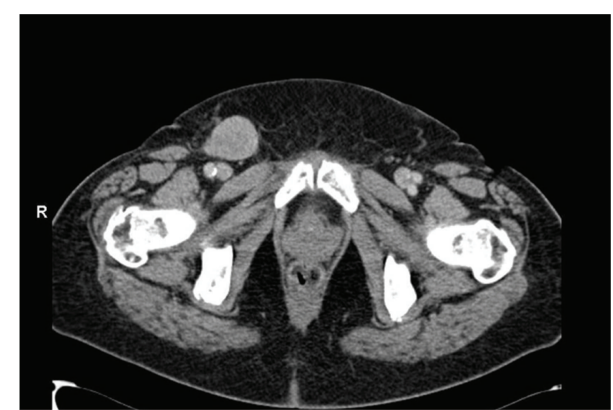

Figure 3: A 68-year-old Caucasian woman with a high grade sarcoma NOS presenting with a RLNM.

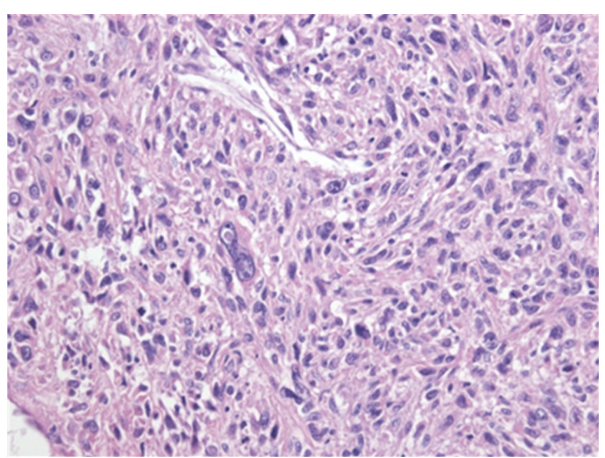

Figure 4: Microscopic view (400x) of the tumor located in a lymph node, diagnosed to be a localization of a high grade sarcoma NOS. It developed as a result of the differentiation of the primary tumor 10 years ago. This was concluded based on the morphology, clinical history, and immunoprofile (vimentin positive) of this tumor.

3.2. Lymph Node Metastases. Unlike distant metastases, regional lymph node metastases (RLNMs) in soft tissue sarcoma are rare. STS progress to regional lymph node metastases in $1.75 \%-5.9 \%$ [9-12]. Furthermore lymphatic spread is more frequently associated with certain histologic types, such as rhabdomyosarcoma, epitheloid sarcoma, clear cell sarcoma, or vascular sarcoma. Regional lymph node involvement is seen in over $10 \%$ of all patients [9-12]. Dermatofibrosarcoma protuberans and NOS-type sarcomas rarely spread to the regional lymph nodes (2\%) (Table 1). Moreover RLNMs occur more often in patients having sarcomas of the lower extremities. The incidence of a RLNM in patients with a sarcoma of the lower extremity is reported up to $24 \%$ (Table 2) [9-12].

There is no research done in survival rates for patients with DFSP or NOS-type sarcomas and RLNMs. The median overall survival of patients with RLNM was 12.7 months, ranging from 0 to 40.7 months [9-12]. The 1-, 5-, and 10-year overall survival rates are $81.5 \%, 33.3 \%$, and $20 \%$. After the diagnosis of a regional lymph node the 1- and 5-year survival rates dropped to $55.5 \%$ and $12.8 \%$ [9-12]. The average time to develop RLNM is 27 months ranging from 1 month to 16 years after primary surgical resection [9-12]. For DFSP in general the 5-year survival rate was up to $99 \%[6,15]$. 
TABLE 1: Four studies on the number of patients with a STS who develop RLNM.

\begin{tabular}{lccc}
\hline Type of tumor & $\begin{array}{c}\text { Number of } \\
\text { patients }\end{array}$ & $\begin{array}{c}\text { Number of } \\
\text { RLNMs }\end{array}$ & Percentage \\
\hline $\begin{array}{l}\text { Synovial sarcoma } \\
\quad \text { Mazeron and Suit [9] }\end{array}$ & 15 & 0 & $0 \%$ \\
$\quad$ Review Mazeron and & 851 & 117 & $14 \%$ \\
$\quad$ Suit [9] & 145 & 2 & $1 \%$ \\
$\quad$ Fong et al. [10] & 111 & 4 & $4 \%$ \\
$\quad$ Daigeler et al. [11] & 171 & 7 & $4 \%$ \\
$\quad$ Behranwala et al. [12] & 1293 & 130 & $\mathbf{1 0} \%$ \\
\hline Total & & & \\
\hline Fibrosarcoma & 45 & 0 & $0 \%$ \\
$\quad$ Mazeron and Suit [9] & 215 & 54 & $25 \%$ \\
$\quad$ Review Mazeron and & 162 & 0 & $0 \%$ \\
Suit [9] & 45 & 1 & $2 \%$ \\
Fong et al. [10] & 132 & 1 & $1 \%$ \\
$\quad$ Daigeler et al. [11] & 599 & 56 & $\mathbf{9} \%$ \\
$\quad$ Behranwala et al. [12] & & &
\end{tabular}

Malignant

fibrohistiocytoma

\begin{tabular}{lccc} 
Mazeron and Suit [9] & 48 & 1 & $2 \%$ \\
$\begin{array}{l}\text { Review Mazeron and } \\
\text { Suit [9] }\end{array}$ & 823 & 84 & $10 \%$ \\
Fong et al. [10] & 316 & 8 & $3 \%$ \\
Behranwala et al. [12] & 235 & 3 & $1 \%$ \\
\hline Total & 1422 & 96 & $7 \%$ \\
\hline
\end{tabular}

Neurofibrosarcoma

\begin{tabular}{lccc} 
Mazeron and Suit [9] & 20 & 1 & $5 \%$ \\
Review Mazeron and & 476 & 3 & $1 \%$ \\
Suit [9] & 96 & 2 & $2 \%$ \\
Fong et al. [10] & 94 & 3 & $3 \%$ \\
$\quad$ Daigeler et al. [11] & 95 & 4 & $4 \%$ \\
$\quad$ Behranwala et al. [12] & 781 & 13 & $\mathbf{2} \%$ \\
\hline Total & & & \\
\hline Liposarcoma & 55 & 2 & $4 \%$ \\
$\quad$ Mazeron and Suit [9] & 504 & 16 & $3 \%$ \\
$\quad$ Review Mazeron and & 403 & 3 & $1 \%$ \\
Suit [9] & 333 & 1 & $0 \%$ \\
Fong et al. [10] & 340 & 3 & $1 \%$ \\
$\quad$ Daigeler et al. [11] & 1635 & 25 & $\mathbf{2} \%$ \\
$\quad$ Behranwala et al. [12] & & & \\
\hline Total & 15 & 5 & $33 \%$ \\
\hline Rhabdomyosarcoma & 1354 & 201 & $15 \%$ \\
Mazeron and Suit [9] & 123 & 13 & $11 \%$ \\
Review Mazeron and & 50 & 3 & $6 \%$ \\
Suit [9] & 54 & 12 & $22 \%$ \\
Fong et al. [10] & 1596 & 234 & $\mathbf{1 5} \%$ \\
\hline $\begin{array}{l}\text { Daigeler et al. [11] } \\
\text { Behranwala et al. [12] }\end{array}$ & & \\
\hline Total & & & \\
\hline
\end{tabular}

TABLE 1: Continued.

\begin{tabular}{|c|c|c|c|}
\hline Type of tumor & $\begin{array}{c}\text { Number of } \\
\text { patients }\end{array}$ & $\begin{array}{c}\text { Number of } \\
\text { RLNMs }\end{array}$ & Percentage \\
\hline \multicolumn{4}{|l|}{ Leiomyosarcoma } \\
\hline Mazeron and Suit [9] & 30 & 1 & $3 \%$ \\
\hline $\begin{array}{l}\text { Review Mazeron and } \\
\text { Suit [9] }\end{array}$ & 524 & 21 & $4 \%$ \\
\hline Fong et al. [10] & 328 & 9 & $3 \%$ \\
\hline Daigeler et al. [11] & 167 & 1 & $1 \%$ \\
\hline Behranwala et al. [12] & 483 & 13 & $3 \%$ \\
\hline Total & 1532 & 45 & $3 \%$ \\
\hline \multicolumn{4}{|l|}{ Vascular sarcoma } \\
\hline Mazeron and Suit [9] & 14 & 2 & $14 \%$ \\
\hline Fong et al. [10] & 37 & 5 & $14 \%$ \\
\hline Daigeler et al. [11] & 38 & 3 & $8 \%$ \\
\hline Behranwala et al. [12] & 46 & 5 & $11 \%$ \\
\hline Total & 135 & 15 & $11 \%$ \\
\hline \multicolumn{4}{|l|}{ Epithelioid sarcoma } \\
\hline Mazeron and Suit [9] & 7 & 5 & $71 \%$ \\
\hline $\begin{array}{l}\text { Review Mazeron and } \\
\text { Suit [9] }\end{array}$ & 70 & 14 & $20 \%$ \\
\hline Fong et al. [10] & 12 & 2 & $17 \%$ \\
\hline Daigeler et al. [11] & 28 & 6 & $21 \%$ \\
\hline Behranwala et al. [12] & 27 & 5 & $19 \%$ \\
\hline Total & 144 & 32 & $22 \%$ \\
\hline \multicolumn{4}{|l|}{ Clear cell } \\
\hline $\begin{array}{l}\text { Review Mazeron and } \\
\text { Suit [9] }\end{array}$ & 40 & 11 & $28 \%$ \\
\hline Daigeler et al. [11] & 14 & 3 & $21 \%$ \\
\hline Behranwala et al. [12] & 25 & 1 & $4 \%$ \\
\hline Total & 79 & 15 & $19 \%$ \\
\hline \multicolumn{4}{|l|}{ NOS } \\
\hline Mazeron and Suit [9] & 42 & 2 & $5 \%$ \\
\hline Fong et al. [10] & 27 & 0 & $0 \%$ \\
\hline Daigeler et al. [11] & 268 & 2 & $1 \%$ \\
\hline Behranwala et al. [12] & 10 & 1 & $10 \%$ \\
\hline Total & 347 & 5 & $1 \%$ \\
\hline \multicolumn{4}{|l|}{$\begin{array}{l}\text { Dermatofibrosarcoma } \\
\text { Protuberans }\end{array}$} \\
\hline Daigeler et al. [11] & 48 & 1 & $2 \%$ \\
\hline Behranwala et al. [12] & 43 & 1 & $2 \%$ \\
\hline Total & 91 & 2 & $2 \%$ \\
\hline
\end{tabular}

3.3. Therapy. To our knowledge there is no evidence of the single use of radiotherapy or chemotherapy in the treatment of STS with RLNM, nor is there any evidence for the specific treatment of primary NOS-type STS. For DFSP radiation therapy is only used in extremely large and recurrent tumors, and there is currently only a little role for chemotherapy [18].

In general for the treatment of a primary STS, radiation therapy combined with surgery is recommended only for intermediate and high grade malignancies [19, 20]. For low grade malignancies reexcision alone is favored over radiotherapy, and radiation therapy is not recommended with 
TABLE 2: Three studies on the number of patients with a STS who developed RLNM in various anatomical locations.

\begin{tabular}{|c|c|c|c|}
\hline Anatomical location & $\begin{array}{c}\text { Number of } \\
\text { patients }\end{array}$ & $\begin{array}{l}\text { Number of } \\
\text { RLNMs }\end{array}$ & Percentage \\
\hline \multicolumn{4}{|l|}{ Head and Neck } \\
\hline Mazeron and Suit [9] & 20 & 3 & $15 \%$ \\
\hline Fong et al. [10] & 45 & 5 & $11 \%$ \\
\hline Behranwala et al. [12] & 75 & 6 & $8 \%$ \\
\hline Total & 140 & 14 & $10 \%$ \\
\hline \multicolumn{4}{|l|}{ Upper extremity } \\
\hline Mazeron and Suit [9] & 42 & 6 & $14 \%$ \\
\hline Fong et al. [10] & 47 & 7 & $15 \%$ \\
\hline Behranwala et al. [12] & 70 & 7 & $10 \%$ \\
\hline Total & 159 & 20 & $13 \%$ \\
\hline \multicolumn{4}{|l|}{ Lower extremity } \\
\hline Mazeron and Suit [9] & 122 & 6 & $5 \%$ \\
\hline Fong et al. [10] & 46 & 19 & $41 \%$ \\
\hline Behranwala et al. [12] & 73 & 33 & $45 \%$ \\
\hline Total & 241 & 58 & $24 \%$ \\
\hline \multicolumn{4}{|l|}{ Trunk } \\
\hline Mazeron and Suit [9] & 102 & 4 & $4 \%$ \\
\hline Fong et al. [10] & 500 & 5 & $1 \%$ \\
\hline Behranwala et al. [12] & 73 & 11 & $15 \%$ \\
\hline Total & 675 & 20 & $3 \%$ \\
\hline \multicolumn{4}{|l|}{$\begin{array}{l}\text { Abdominal and } \\
\text { Thoracic Viscera }\end{array}$} \\
\hline Mazeron and Suit [9] & 23 & 0 & $0 \%$ \\
\hline Fong et al. [10] & 43 & 3 & $7 \%$ \\
\hline Behranwala et al. [12] & 73 & 11 & $15 \%$ \\
\hline Total & 139 & 14 & $10 \%$ \\
\hline
\end{tabular}

negative margins after surgery $[19,20]$. The optimal timing of adjuvant radiation therapy in primary STS is not clear. In a prospective study randomizing for pre- or postoperative radiotherapy (RT) among 190 patients, there was a higher rate of acute wound complications with preoperative RT. Moreover there was a higher amount of patients with late complications, such as edema or fibrosis, for postoperative RT. Nevertheless there was no difference in survival rate between the two types of radiotherapy [21]

In general chemotherapy as part of the treatment of a primary STS in adults has not demonstrated an overall survival advantage $[22,23]$, nor is adjuvant chemotherapy considered to be a standard practice, in some studies even showing a worse 5 -year survival rate $[24,25]$. Furthermore, neo-adjuvant chemotherapy failed to show any benefit, awaiting the results of larger randomized trials [26, 27]. In contrast, hyperthermia has proven its efficacy in combination with neoadjuvant chemotherapy. In high-risk patients $(>5 \mathrm{~cm}$ tumor size, grade 2 or 3 , and/or deep to the fascia) it increases the benefit of chemotherapy alone [28-30].

The role of a sentinel lymph node biopsy(SLNB) for staging of patients with primary STS is unknown. In many cases, despite radical lymphadenectomy, patients with positive lymph node found with a SLNB procedure developed distant metastases; also a serious number of patients with positive lymph nodes remained disease-free. A multicenter trial would be necessary to determine the efficacy of SLNB [31-36].

At last we know that radical lymphadenectomy in case of RLNM remains the appropriate treatment so far [9]. Patients not treated with a radical lymphadenectomy had a shorter median survival than patients without a radical lymphadenectomy. Patients without appropriate treatment had a 5-year survival rate of $0 \%$ (median survival of 4.3 months) versus $46 \%$ (median survival of 16.3 months) after a radical excision of the regional lymph nodes [9].

\section{Conclusion}

To the best of our knowledge our case was the first description of a case of a DFSP followed by a high grade sarcoma NOS presenting with a RLNM. If we review the literature, there was a minor a priori chance of a RLNM in both types of STS. For DFSP the risk for a regional lymph node metastasis is as big as the risk for a distant metastasis; this is unknown for NOS-type soft tissue sarcoma. Nevertheless the standard of care in the Netherlands does not include a regular analysis of the regular nodes, but does include an X-ray for lung metastasis.

Furthermore, we should urge caution in specific histological types and also in certain anatomical locations as the risk for an RLNM in rhabdomyosarcoma, epitheloid sarcoma, clear cell sarcoma, or a vascular sarcoma and also in STS of the lower extremities might transcend the risk for a distant lung metastasis.

According to the literature the best practice for a RLNM is radical surgery. There is yet no evidence on the therapy of RNLM with radiotherapy or chemotherapy but in primary tumors radiotherapy is proven effective.

\section{Consent}

Informed consent was obtained from the patient for publication of this case report and any accompanying images.

\section{Conflict of Interests}

The authors declare that they have no conflict of interests.

\section{References}

[1] J. W. W. Coebergh, J. A. A. M. van Dijck, M. L. G. JanssenHeijnen, and O. Visser, Childhood Cancer in the Netherlands, 1989-1997, Dutch Association of Cancer Registries, Utrecht, The Netherlands, 2000.

[2] P. Kaatsch, "Epidemiology of childhood cancer," Cancer Treatment Reviews, vol. 36, no. 4, pp. 277-285, 2010.

[3] V. V. I. Kankercentra, Incidence of Cancer in the Netherlands 1997, Ninth Report of the Netherlands Cancer Registry, 1997.

[4] P. H. A. Nijhuis, M. Schaapveld, R. Otter, W. M. Molenaar, W. T. A. Van Der Graaf, and H. J. Hoekstra, "Epidemiological aspects of soft tissue sarcomas (STS)-consequences for the design of 
clinical STS trials," European Journal of Cancer, vol. 35, no. 12, pp. 1705-1710, 1999.

[5] A. Jemal, R. Siegel, J. Xu, and E. Ward, "Cancer statistics, 2010," CA Cancer Journal for Clinicians, vol. 60, no. 5, pp. 277-300, 2010.

[6] V. D. Criscione and M. A. Weinstock, "Descriptive epidemiology of dermatofibrosarcoma protuberans in the United States, 1973 to 2002," Journal of the American Academy of Dermatology, vol. 56, no. 6, pp. 968-973, 2007.

[7] J. F. Huth and F. R. Eilber, "Patterns of metastatic spread following resection of extremity soft-tissue sarcomas and strategies for treatment," Seminars in Surgical Oncology, vol. 4, no. 1, pp. 2026, 1988.

[8] C. S. Trovik, H. C. F. Bauer, T. A. Alvegård et al., "Surgical margins, local recurrence and metastasis in soft tissue sarcomas: 559 surgically-treated patients from the Scandinavian Sarcoma Group Register," European Journal of Cancer, vol. 36, no. 6, pp. 710-716, 2000.

[9] J. J. Mazeron and H. D. Suit, "Lymph nodes as sites of metastases from sarcomas of soft tissue," Cancer, vol. 60, no. 8, pp. 18001808, 1987.

[10] Y. Fong, D. G. Coit, J. M. Woodruff, and M. F. Brennan, "Lymph node metastasis from soft tissue sarcoma in adults: analysis of data from a prospective database of 1772 sarcoma patients," Annals of Surgery, vol. 217, no. 1, pp. 72-78, 1993.

[11] A. Daigeler, C. Kuhnen, R. Moritz et al., "Lymph node metastases in soft tissue sarcomas-a single center analysis of 1,597 patients," Langenbeck's Archives of Surgery, vol. 394, no. 2, pp. 321-329, 2009.

[12] K. A. Behranwala, R. A'Hern, A. M. Omar, and J. M. Thomas, "Prognosis of lymph node metastasis in soft tissue sarcoma," Annals of Surgical Oncology, vol. 11, no. 7, pp. 714-719, 2004.

[13] K. G. Billingsley, M. E. Burt, E. Jara et al., "Pulmonary metastases from soft tissue sarcoma: analysis of patterns of disease and postmetastasis survival," Annals of Surgery, vol. 229, no. 5, pp. 602-612, 1999.

[14] P. W. T. Pisters, D. H. Y. Leung, J. Woodruff, W. Shi, and M. F. Brennan, "Analysis of prognostic factors in 1,041 patients with localized soft tissue sarcomas of the extremities," Journal of Clinical Oncology, vol. 14, no. 5, pp. 1679-1689, 1996.

[15] W. B. Bowne, C. R. Antonescu, D. H. Y. Leung et al., "Dermatofibrosarcoma protuberans: a clinicopathologic analysis of patients treated and followed at a single institution," Cancer, vol. 88, no. 12, pp. 2711-2720, 2000.

[16] W. B. Al-Refaie, R. H. I. Andtbacka, J. Ensor et al., "Lymphadenectomy for isolated lymph node metastasis from extremity soft-tissue sarcomas," Cancer, vol. 112, no. 8, pp. 18211826, 2008.

[17] M. Christie-Large, S. L. J. James, L. Tiessen, A. M. Davies, and R. J. Grimer, "Imaging strategy for detecting lung metastases at presentation in patients with soft tissue sarcomas," European Journal of Cancer, vol. 44, no. 13, pp. 1841-1845, 2008.

[18] B. Bogucki, I. Neuhaus, and E. A. Hurst, "Dermatofibrosarcoma protuberans: a review of the literature," Dermatologic Surgery. In press.

[19] S. A. Rosenberg, J. Tepper, E. Glatstein et al., “The treatment of soft-tissue sarcomas of the extremities. Prospective randomized evaluations of (1) limb-sparing surgery plus radiation therapy compared with amputation and (2) the role of adjuvant chemotherapy," Annals of Surgery, vol. 196, no. 3, pp. 305-315, 1982.
[20] L. J. Sheplan and J. J. Juliano, "Use of radiation therapy for patients with soft-tissue and bone sarcomas," Cleveland Clinic Journal of Medicine, vol. 77, supplement 1, pp. S27-S29, 2010.

[21] B. O'Sullivan, A. M. Davis, R. Turcotte et al., "Preoperative versus postoperative radiotherapy in soft-tissue sarcoma of the limbs: a randomised trial," The Lancet, vol. 359, no. 9325, pp. 2235-2241, 2002.

[22] V. H. Bramwell, D. Anderson, and M. L. Charette, "Doxorubicin-based chemotherapy for the palliative treatment of adult patients with locally advanced or metastatic soft tissue sarcoma," Cochrane Database of Systematic Reviews, no. 3, Article ID CD003293, 2003.

[23] R. Wesolowski and G. T. Budd, "Use of chemotherapy for patients with bone and soft-tissue sarcomas," Cleveland Clinic Journal of Medicine, vol. 77, supplement 1, pp. S23-S26, 2010.

[24] P. G. Casali and P. Picci, "Adjuvant chemotherapy for soft tissue sarcoma," Current Opinion in Oncology, vol. 17, no. 4, pp. 361365, 2005.

[25] Sarcoma Meta-Analysis Collaboration, "Adjuvant chemotherapy for localised resectable soft-tissue sarcoma of adults: metaanalysis of individual data," The Lancet, vol. 350, no. 9092, pp. 1647-1654, 1997.

[26] E. Gortzak, A. Azzarelli, J. Buesa et al., "A randomised phase II study on neo-adjuvant chemotherapy for 'high-risk' adult softtissue sarcoma," European Journal of Cancer, vol. 37, no. 9, pp. 1096-1103, 2001.

[27] S. R. Grobmyer, R. G. Maki, G. D. Demetri et al., "Neo-adjuvant chemotherapy for primary high-grade extremity soft tissue sarcoma," Annals of Oncology, vol. 15, no. 11, pp. 1667-1672, 2004.

[28] R. D. Issels, S. Abdel-Rahman, C. M. Wendtner et al., "Neoadjuvant chemotherapy combined with regional hyperthermia (RHT) for locally advanced primary or recurrent high-risk adult soft-tissue sarcomas (STS) of adults: long-term results of a phase II study," European Journal of Cancer, vol. 37, no. 13, pp. 1599-1608, 2001.

[29] R. D. Issels, L. H. Lindner, J. Verweij et al., "Neo-adjuvant chemotherapy alone or with regional hyperthermia for localised high-risk soft-tissue sarcoma: a randomised phase 3 multicentre study," The Lancet Oncology, vol. 11, no. 6, pp. 561-570, 2010.

[30] C. M. Wendtner, S. Abdel-Rahman, M. Krych et al., "Response to neoadjuvant chemotherapy combined with regional hyperthermia predicts long-term survival for adult patients with retroperitoneal and visceral high-risk soft tissue sarcomas," Journal of Clinical Oncology, vol. 20, no. 14, pp. 3156-3164, 2002.

[31] D. Andreou and P. U. Tunn, "Sentinel node biopsy in soft tissue sarcome," Recent Results in Cancer Research, vol. 179, pp. 25-36, 2009.

[32] D. Baratti, E. Pennacchioli, P. G. Casali et al., "Epithelioid sarcoma: prognostic factors and survival in a series of patients treated at a single institution," Annals of Surgical Oncology, vol. 14, no. 12, pp. 3542-3551, 2007.

[33] D. G. Blazer III, M. S. Sabel, and V. K. Sondak, "Is there a role for sentinel lymph node biopsy in the management of sarcoma?" Surgical Oncology, vol. 12, no. 3, pp. 201-206, 2003.

[34] U. N. Maduekwe, F. J. Hornicek, D. S. Springfield et al., "Role of sentinel lymph node biopsy in the staging of synovial, epithelioid, and clear cell sarcomas," Annals of Surgical Oncology, vol. 16, no. 5, pp. 1356-1363, 2009.

[35] P. U. Tunn, D. Andreou, H. Illing, B. Fleige, S. Dresel, and P. M. Schlag, "Sentinel node biopsy in synovial sarcoma," European Journal of Surgical Oncology, vol. 34, no. 6, pp. 704-707, 2008. 
[36] A. C. J. van Akkooi, C. Verhoef, A. N. van Geel, M. Kliffen, A. M. M. Eggermont, and J. H. W. de Wilt, "Sentinel node biopsy for clear cell sarcoma," European Journal of Surgical Oncology, vol. 32, no. 9, pp. 996-999, 2006. 


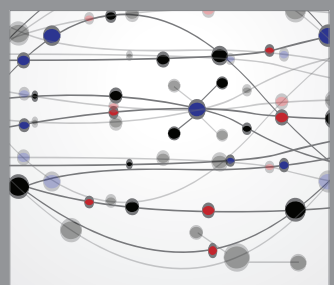

The Scientific World Journal
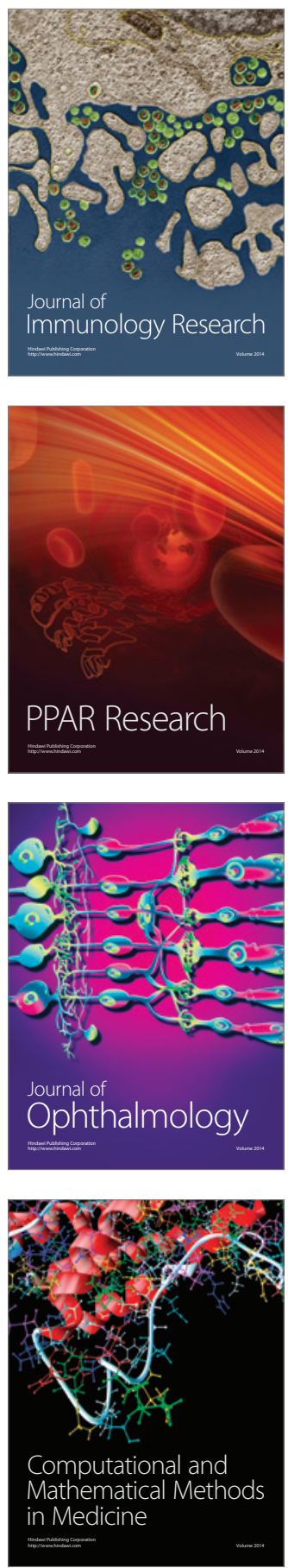

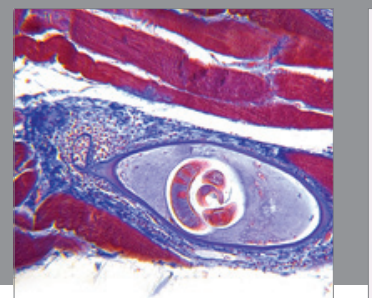

Gastroenterology

Research and Practice
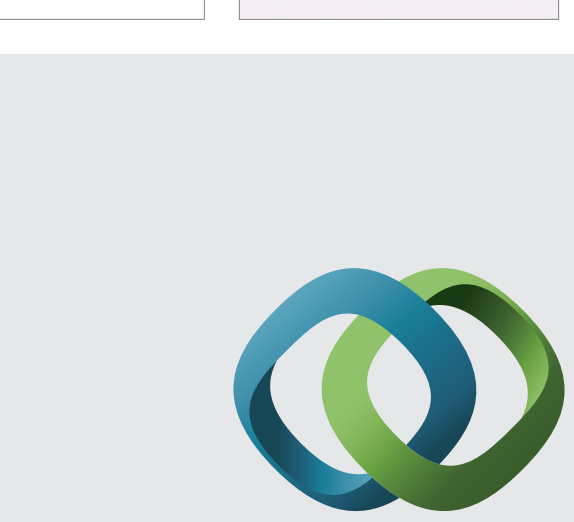

\section{Hindawi}

Submit your manuscripts at

http://www.hindawi.com
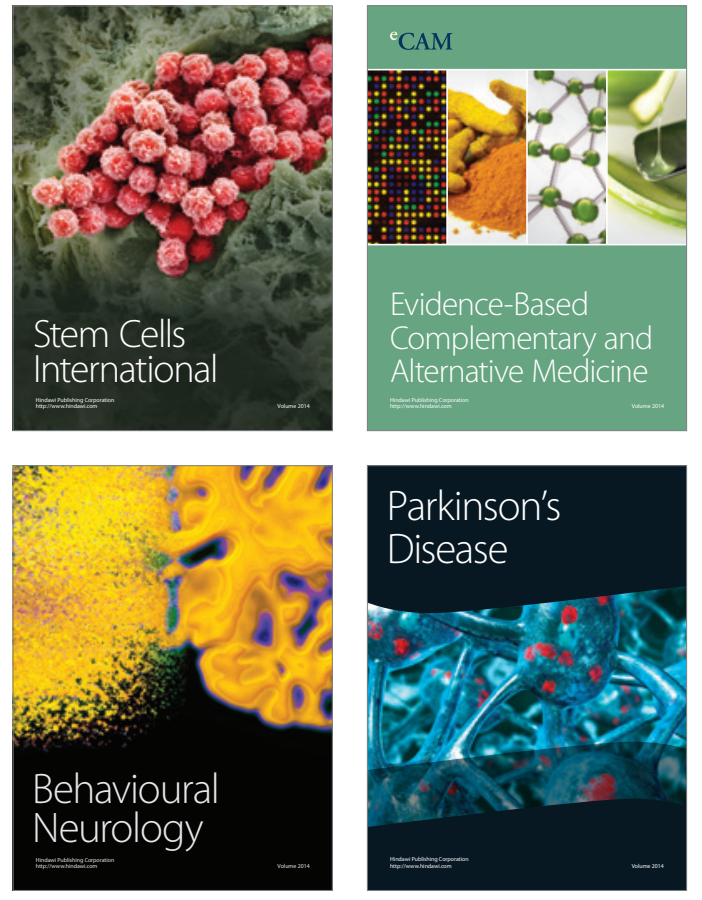
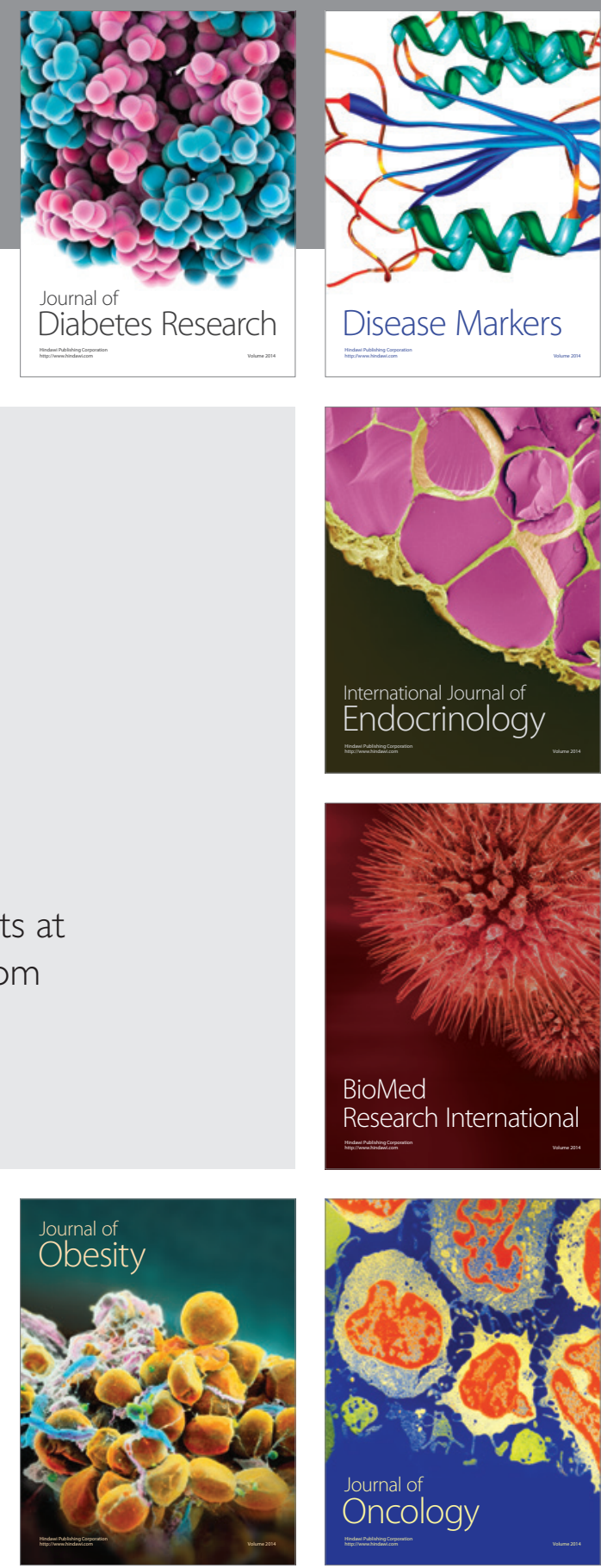

Disease Markers
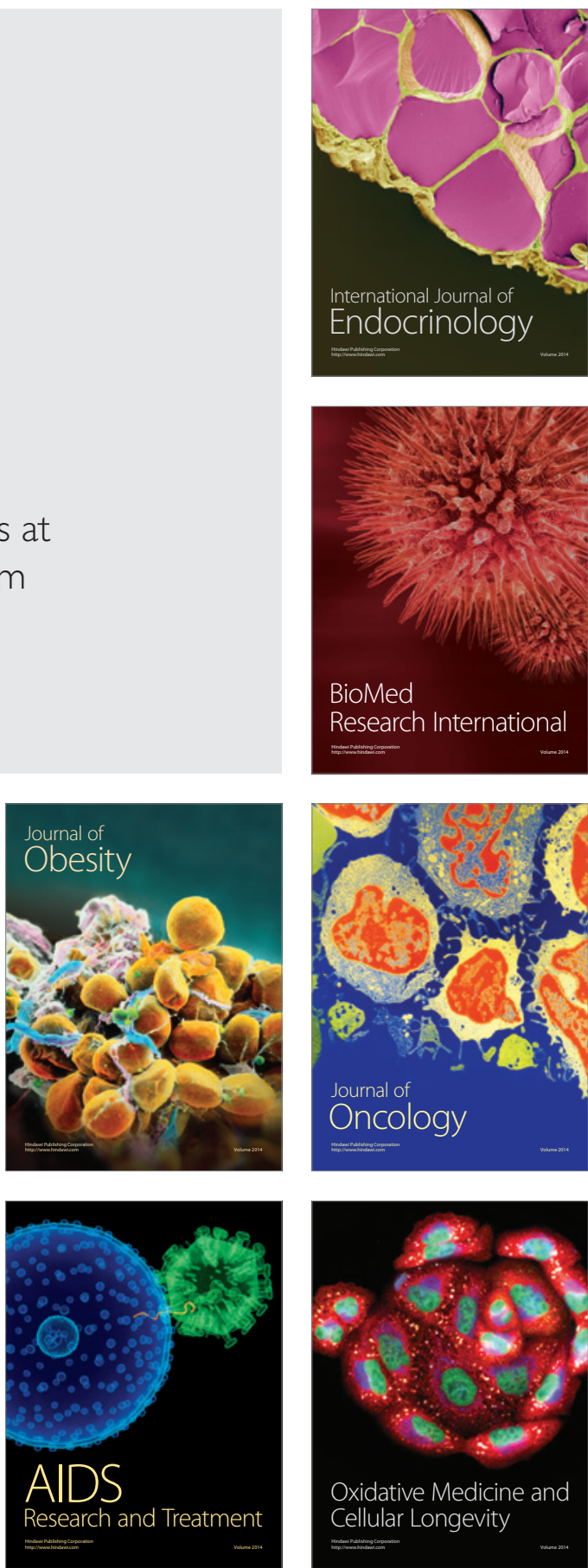